Jurnal Unifikasi, ISSN 2354-5976

Vol. 3 No. 2 Juli 2016

\title{
ALTERNATIF PERLINDUNGAN HUKUM ATAS HAK MEREK KOLEKTIF GENTENG JATIWANGI GUNA MENGURANGI PERSAINGAN USAHA DI KABUPATEN MAJALENGKA
}

\author{
Anthon Fathanudien \\ Fakultas Hukum Universitas Kuningan, anthonfathanudien@yahoo.co.id
}

\begin{abstract}
In the era of global trade and the free market, the brand holds a very important role that requires more adequate regulatory system. The era of global trade can only be sustained if there is a healthy business competition climate. One piece of Intellectual Property Rights should be regulated and protected that brand. The need for legal protection of mereksemakin expanded rapidly after the high incidence of people doing imitation-imitation. One brand that needs to be protected is the brand Tile Jatiwangi Majalengka. Brand protection is already regulated in Law Number 15 of 2001 on Marks, but in fact many brands of tiles Jatiwangi not registered with the Directorate General of Intellectual Property that is not protected by law.

The problem in this research is How Alternative Legal Protection of Collective Brands Top Right tile Jatiwangi To Reduce Competition in Majalengka and How the role of Local Government Majalengka against collective trademark rights in defending the existence Jatiwangi tiles. This research method using empirical juridical approach and specification of descriptive analytical research that explains the Top Alternative Legal Protection of Trademark Rights Collective tile Jatiwangi To Reduce Competition and Local Government explained Majalengka attitude towards collective trademark rights in defending the existence Jatiwangi tiles.

From this research result that Alternative Legal Protection of Collective Brands Top Right tile Jatiwangi To Reduce Competition which is majority-owned unit of Small and Medium Enterprises (SMEs). By using the collective brand and marketing together can reduce unfair competition between the owners of the tile industry Jatiwangi. Jatiwangi tile industry has a huge contribution to the economy of surrounding communities for labor-intensive and has a substantial investment and become a mainstay industry of Majalengka. Therefore, local governments must participate in order Majalengka tile Jatiwangi existence has always existed, the Local Government Majalengka themselves so that the tile industry Jatiwangi legal protection as stipulated in Law No. 15 of 2001 on Marks. Local Government Majalengka in this case the Department of Trade and Industry supports the use of collective marks for the legal protections of brands Jatiwangi tile. Majalengka Local Government will raise the dissemination of the importance of legal protection of the mark so that the owners of the tile industry Jatiwangi understand the importance of the legal protection of the brand.
\end{abstract}

Keywords: Alternative Legal Protection, Collective Brands, Tile Jatiwangi 


\begin{abstract}
ABSTRAK
Pada era perdagangan global dan pasar bebas, merek memegang peranan yang sangat penting yang memerlukan sistem pengaturan yang lebih memadai. Era perdagangan global hanya dapat dipertahankan jika terdapat iklim persaingan usaha sehat. Salah satu bagian Hak Kekayaan Intelektual yang harus diatur dan dilindungi yaitu merek. Kebutuhan adanya perlindungan hukum atas mereksemakin berkembang pesat setelah banyaknya kejadian orang yang melakukan peniruan-peniruan. Salah satu merek yang perlu dilindungi yaitu merek Genteng Jatiwangi Kabupaten Majalengka. Perlindungan merek sebenarnya sudah diatur dalam Undang-undang Nomor 15 Tahun 2001 tentang Merek, namun faktanya banyak merek Genteng Jatiwangi belum terdaftar di Direktorat Jenderal Hak Kekayaan Intelektual sehingga belum mendapat perlindungan hukum.

Permasalahan dalam penelitian ini yaitu Bagaimana Alternatif Perlindungan Hukum Atas Hak Merek Kolektif Genteng Jatiwangi Guna Mengurangi Persaingan Usaha di Kabupaten Majalengka dan Bagaimana peran Pemerintah Daerah Kabupaten Majalengka terhadap hak merek kolektif dalam mempertahankan keberadaan Genteng Jatiwangi. Metode penelitian ini menggunakan pendekatan yuridis empiris dan spesifikasi penelitian deskriptif analitis yaitu menjelaskan mengenai Alternatif Perlindungan Hukum Atas Hak Merek Kolektif Genteng Jatiwangi Guna Mengurangi Persaingan Usaha dan menjelaskan sikap Pemerintah Daerah Kabupaten Majalengka terhadap hak merek kolektif dalam mempertahankan keberadaan Genteng Jatiwangi.

Dari penelitian ini diperoleh hasil bahwa Alternatif Perlindungan Hukum Atas Hak Merek Kolektif Genteng Jatiwangi Guna Mengurangi Persaingan Usaha yang sebagian besar dimiliki Unit Usaha Kecil dan Menengah (UKM). Dengan menggunakan merek kolektif dan pemasaran bersama dapat mengurangi tingkat persaingan usaha tidak sehat di antara para pemilik industri genteng Jatiwangi. Industri genteng Jatiwangi mempunyai kontribusi yang besar terhadap perekonomian masyarakat sekitarnya karena banyak menyerap tenaga kerja dan memiliki investasi yang besar dan menjadi industri andalan Majalengka. Oleh karena itu, Pemerintah Daerah Majalengka harus ikut berperan agar keberadaan genteng Jatiwangi selalu eksis, Pemerintah Daerah Majalengka berperan agar industri genteng Jatiwangi mendapat perlindungan hukum sebagaimana diatur dalam Undang-undang Nomor 15 Tahun 2001 tentang Merek. Pemerintah Daerah Majalengka dalam hal ini Dinas Perindustrian dan Perdagangan mendukung penggunaan merek kolektif untuk perlindungan hukum atas merek genteng Jatiwangi. Pemerintah Daerah Majalengka lebih memperbanyak sosialisasi tentang pentingnya perlindungan hukum atas merek sehingga para pemilik industri genteng Jatiwangi memahami akan pentingnya perlindungan hukum atas merek.
\end{abstract}

Kunci : Alternatif Perlindungan Hukum, Merek Kolektif, Genteng Jatiwangi 


\section{A. Pendahuluan}

Perkembangan perekonomian dunia, termasuk sektor industri dan sarana teknologi yang pesat membuat cara berpikir manusia menjadi semakin kreatif dan inovatif. Hal ini terbukti dengan semakin banyaknya hasil karya kreatif manusia yang diwujudkan dengan menggunakan daya, rasa, dan karsa berdasarkan kemampuan intelektualnya dalam rangka memperkaya kehidupannya ${ }^{1}$. Sejauh ini, suatu karya lazimnya diciptakan dengan proses yang panjang karena membutuhkan waktu, tenaga dan biaya yang tidak sedikit. Oleh karena itu, sudah sepantasnya pencipta atas karyakarya yang kreatif, inventor teknologi, pendesain dan pembuat merek dagang dihargai dan diberikan perlindungan hukum yang efektif.

Hak Kekayaan Intelektual merupakan hak yang timbul dari hasil olah pikir intelektual manusia yang menghasilkan suatu karya yang berguna bagi manusia. Dengan demikian, obyek yang diatur dalam ruang lingkup Hak Kekayaan Intelektual adalah karya-karya yang timbul karena kemampuan intelektual manusia ${ }^{2}$. Apabila diperhatikan dalam sistem hukum perdata di Indonesia, Hak Kekayaan Intelektual masuk pada hukum harta kekayaan yang terdiri dari dua bagian yaitu hukum perikatan, dalam Pasal 1233 KUH Perdata dan hukum benda

\footnotetext{
${ }^{1}$ Suyud Margono, Komentar Atas Undang-Undang Rahasia Dagang, Desain Industri, Desain Letak Sirkuit Terpadu, CV. Novindo Pustaka Mandiri, Jakarta, 2001, hal. 4

2 Direktorat Jenderal Hak Kekayaan Intelektual Departemen Kehakiman dan HAM RI , Buku Panduan Hak Kekayaan Intelektual, Dirjen HAKI Departemen Kehakiman dan HAM RI, Tangerang, 2003, hal. 4
}

dalam Pasal 499 KUH Perdata ${ }^{3}$. Pada konsep harta kekayaan, setiap benda selalu ada pemiliknya, setiap pemilik benda suatu benda mempunyai hak atas benda miliknya, yang biasanya disebut "Hak Milik" dengan demikian pemilik berhak untuk menikmati dan menguasai benda tersebut sepenuhnya ${ }^{4}$. Dalam beberapa tahun terakhir, Hak Kekayaan Intelektual kian menjadi isu yang sangat penting yang selalu mendapat perhatian dalam masyarakat, baik dalam forum nasional maupun internasional. Pentingnya Hak Kekayaan Intelektual dalam pembangunan ekonomi dan perdagangan telah memacu dimulainya era pembangungan ekonomi berdasarkan ilmu pengetahuan ${ }^{5}$.

Dalam khasanah ilmu pengetahuan, intelektual manusia diartikan sebagai kekayaan intelektual yang dapat dimiliki oleh pribadi manusia sebagai hak. Dengan kata lain bahwa Hak Kekayaan Intelektual secara sederhana merupakan kekayaan yang timbul atau lahir dari kemampuan intelektual manusia. Karya-karya yang timbul atau lahir dari kemampuan intelektual manusia dapat berupa karya-karya di bidang teknologi, ilmu pengetahuan, seni dan sastra. Karyakarya tersebut dilahirkan atau dihasilkan atas kemampuan intelektual manusia melalui curahan waktu, tenaga, pikiran, daya cipta, rasa dan karsanya. Hal tersebut yang membedakan Hak Kekayaan Intelektual

\footnotetext{
${ }^{3}$ Ok Saidin, Aspek Hukum Kekayaan Intelektual, PT. Raja Grafindo Persada, Jakarta, 2004. Hal. 11

4 R. Subekti dan R. Tjitrosudibyo, Kitab UndangUndang Hukum Perdata, Pradya Paramita, Jakarta, 1986.

5 Makalah bahan seminar oleh Dr. Agus Sardjono, SH., MH, " Sejarah Dan Perkembangan HAKI Indonesia”, Jakarta, 20 September 2009
} 
dengan jenis kekayaan lain yang juga dapat dimiliki oleh manusia tetapi tidak dihasilkan oleh intelektualitas manusia. Sebagai contoh, kekayaan alam berupa tanah dan tumbuhan yang ada di alam merupakan ciptaan dari sang Pencipta. Meskipun tanah dan tumbuhan dapat dimiliki oleh manusia tetapi tanah dan tumbuhan bukanlah hasil karya intelekual manusia. Hak Kekayaan Intelektual merupakan hak yang berasal dari karya, karsa, dan daya cipta kemampuan intelektualitas manusia yang memiliki manfaat serta berguna dalam menunjang kehidupan dan mempunyai nilai ekonomi. Bentuk nyata dari hasil karya, karsa, dan daya cipta kemampuan intelektualitas manusia tersebut berupa ilmu pengetahuan, teknologi, seni dan sastra.

Salah satu perkembangan yang aktual dan memperoleh perhatian saksama dalam masa sepuluh tahun terakhir ini dan kecenderungan yang masih akan berlangsung di masa yang akan datang adalah semakin meluasnya arus globalisasi, baik di bidang hukum, sosial, ekonomi, budaya, maupun bidang-bidang kehidupan lainnya. Perkembangan teknologi informasi dan transportasi telah menjadikan kegiatan di sektor perdagangan meningkat secara pesat dan bahkan telah menempatkan dunia sebagai pasar tunggal bersama ${ }^{6}$. Globalisasi tetap menempatkan hukum pada tatanan pengatur dalam segala aspek kehidupan masyarakat. Kehidupan berhukum harus dijadikan landasan dalam segala aspek kehidupan ekonomi antar individu atau kelompok hingga pada akhirnya hukum mampu mengintegrasikan atau

\footnotetext{
${ }^{6}$ Adrian Sutedi, Hak atas Kekayaan Intelektual, Sinar Grafika, Jakarta, 2013, hal. 89
}

mengkoordinasikan nilai-nilai yang ada sehingga pada akhirnya terdapat legitimasi bagi pemberlakuan norma hukum. Hukum dijadikan keunggulan atau keutamaan (supremasi) mengingat hukum memiliki fungsi dan melalui fungsi hukum diharapkan kehidupan sosial masyarakat yang menyangkut perilaku dapat berubah ke arah yang lebih baik yaitu disiplin, kesadaran, kepatuhan, tanggung jawab sosial, keadilan, kepastian, dan ketertiban sosial ${ }^{7}$.

Di era Perdagangan globalisasi hanya dapat dapat dipertahankan jika terdapat iklim persaingan usaha yang sehat ${ }^{8}$. Indonesia sebagai negara berkembang harus mampu mengambil langkah yang tepat untuk mengantisipasi segala perubahan dan perkembangan serta kecenderungan globalisasi tersebut. Menurut Bahaudin Darus, bahwa ada beberapa perubahan global yang memerlukan payung hukum agar perubahan tersebut dapat berjalan sebagaimana layaknya, yaitu, pertama, globalisasi informasi dan komunikasi sebagai akibat dan kemajuan teknologi dan sarana/prasarana informasi dengan jangkauan yang makin global, kecepatan tinggi dan kapasitas yang lebih besar untuk menyalurkan berbagai ragam informasi, kedua, globalisasi ekonomi dan perdagangan bebas, globalisasi keuangan dan pemilikan kapital, globalisasi pasar dan gerak lajunya perusahaan, ketiga, globalisasi gaya hidup dan pola konsumsi, globalisasi budaya, globalisasi persepsi dan kesadaran yang mana produk-produk ini dipasarkan,

\footnotetext{
7 Endang Sutrisno, Bunga Rampai Hukum Dan Globalisasi, Genta Press, Yogyakarta, 2007, hal. 115

${ }^{8}$ Ibid
} 
keempat, globalisasi media massa dan media cetak serta media elektronik, kelima, globalisasi politik dan wawasan'. Dahsyatnya arus globalisasi secara sosiologis berdampak sangat mendasar bagi penentuan arah dan pola perubahan maupun tatanan sosial masyarakat ${ }^{10}$. Sebab, Hak Kekayaan Intelektual sebagai bagian dari sistem hukum sangatlah erat kaitannya dengan industri, perdagangan, dan investasi, atau yang secara umum dikenal dengan dunia usaha ${ }^{11}$. Namun pada kenyataannya pemahaman masyarakat akan Hak Kekayaan Intelektual masih belum merata atau dengan kata lain pemahaman masyarakat mengenai hal ini masih perlu diusahakan, diperdalam, dan dikembangkan ${ }^{12}$. Sebagai contoh konkrit, kalangan pencipta seringkali tidak menyadari hak eksklusif yang dimilikinya terutama dalam hal bagaimana mempertahankan hak tersebut, atau seringkali terdapat kesalahan pemahaman masyarakat yang hendak "mematenkan merek dagangnya". Padahal dari segi terminologinya merek dan paten adalah dua hal yang berbeda sehingga untuk mengantisipasi hal tersebut masih dibutuhkan pengembangan dan pemahaman yang lebih dalam bagi masyarakat mengandung arti penting, sifat dan tujuan Hak Kekayaan Intelektual serta perlindungan hukum yang efektif

9 Abdul Manan, Aspek-aspek Pengubah Hukum, Kencana, Jakarta, 2005, hal. 61

10 Satjipto Rahardjo, Pendidikan Hukum Sebagai Pendidikan Manusia, Genta Publishing, Yogyakarta, 2009, hal. 99

11 Ibid

12 Cita Citrawinda Priapantja, Hak atas Kekayaan Intelektual : Tantangan Masa Depan, Badan Penerbit Fakultas Hukum Universitas Indonesia, 2003, hal. ix terhadapnya. Perlindungan hukum terhadap hak kekayaan pribadi telah menjalin faktor kunci dalam pertumbuhan kapitalisme dan ekonomi pasar besar ${ }^{13}$.

Dalam menghadapi perdagangan global atau perdagangan bebas, peranan merek menjadi sangat penting terutama dalam menjaga persaingan usaha yang tidak sehat. Kabupaten Majalengka sebagai sentra produk Genteng Jatiwangi tidak terlepas dari pengaruh perdagangan global yang saat ini sudah terasa di kalangan pengusahapengusaha para pemilik merek Genteng Jatiwangi dan pemahaman akan pentingnya perlindungan hukum terhadap Hak Kekayaan Intelektual terutama bidang merek masih rendah.

Hal ini bisa dilihat dari banyaknya sentra-sentra industri Genteng Jatiwangi di Kabupaten Majalengka yang hanya beberapa orang yang telah mendaftarkan mereknya dan memiliki Sertifikat Merek dari Direktorat Jenderal Hak Kekayaan Intelektual. Namun sebagian besar para pemilik sentra-sentra industri Genteng Jatiwangi di Kabupaten Majalengka belum mengetahui dan memahami akan pentingnya perlindungan merek demi kepastian hukum dan persaingan usaha yang sehat sehingga banyak sekali terjadi pelanggaranpelanggaran di bidang Hak Kekayaan Intelektual khususnya tentang merek baik secara sengaja maupun tidak sengaja. Dalam memasuki pasar bebas, perlindungan hukum atas Hak Kekayaan Intelektual di Indonesia perlu perhatian yang serius dalam menghadapi arus globalisasi baik di bidang

13 Budi Agus Riswandi, Hak Kekayaan Intelektual Dan Budaya Hukum, Rajawali Press, Jakarta, 2005, hal 30 
sosial, ekonomi, budaya, dan bidang-bidang kehidupan lainnya. Sebenarnya peraturan perundang-undangan yang berlaku dan mengatur tentang merek sudah ada dan cukup lengkap seperti Undang-Undang Nomor 15 Tahun 2001, namun masih banyaknya para produsen merek Genteng Jatiwangi di Kabupaten Majalengka tidak segera mendaftarkan mereknya sesuai dengan ketentuan-ketentuan perundangundangan yang berlaku.

Dengan memahami dan mengerti tentang Undang-Undang Nomor 15 Tahun 2001 Tentang Merek maka pemilik Genteng Jatiwangi di Kabupaten Majalengka menyadari akan pentingnya perlindungan hukum merek Genteng Jatiwangi di Kabupaten Majalengka demi kepastian hukum dan persaingan yang sehat diantara para pengusaha sehingga dapat bermanfaat bagi masyarakat sekitarnya. Sebagai salah satu alternatif perlindungan hukum merek Genteng Jatiwangi di Kabupaten Majalengka yaitu dengan pemakaian merek kolektif untuk digunakan bersama-sama guna mengurangi persaingan usaha diantara para pemilik, mengingat banyaknya industriindustri Genteng Jatiwangi di Kabupaten Majalengka yang dikelola oleh industri rumah tangga (home industry) sehingga lebih efektif dan efesien. Dalam mewujudkan perlindungan hukum merek Genteng Jatiwangi di Kabupaten Majalengka, Pemerintahan Daerah Kabupaten Majalengka ikut berperan serta dalam rangka melindungi merek Genteng Jatiwangi sebagai hasil industri asal daerah Kabupaten Majalengka.

\section{B. Perumusan Masalah}

1. Bagaimana Alternatif Perlindungan Hukum Atas Hak Merek Kolektif Genteng Jatiwangi Guna Mengurangi Persaingan Usaha di Kabupaten Majalengka?

2. Bagaimana peran Pemerintah Daerah Kabupaten Majalengka terhadap hak merek kolektif dalam mempertahankan keberadaan Genteng Jatiwangi?

\section{Metode Penelitian}

Metode penelitian yang digunakan oleh penyusun dalam pembahasan penelitian ini adalah metode evaluatif analisis, yaitu suatu metode mengumpulkan dan menyajikan data yang diperoleh untuk menganalisis keadaan yang sebenarnya dan selanjutnya dilakukan analisa rasional berdasarkan acuan yuridis melalui penelitian kepustakaan dan penelitian lapangan. Metode penelitian hukum, menurut Soerjono Soekanto adalah “ suatu kegiatan ilmiah, yang di dasarkan pada metode, sistematika dan pemikiran tertentu, yang bertujuan mempelajari satu atau beberapa gejala hukum tertentu, dengan menganalisanya ${ }^{14}$.

Data dan Sumbernya

1. Data primer atau data empiris yaitu sumber data dari melakukan observasi dan data berupa keterangan-keterangan dari nara sumber, antara lain pengusaha, pengurus Apindo, masyarakat, akademisi dan praktisi hukum.

2. Data sekunder yang digunakan dalam penelitian ini, Penggunaan data

14 Soerjono Soekanto, Pengantar Penelitian Hukum.cet.2007, ( Jakarta : UI Press, 1984), hlm.5 
sekunder ini karena memiliki beberapa keuntungan, yaitu ${ }^{15}$ :

a. Pada umumnya data sekunder dalam keadaan siap terbuat dan dapat dipergunakan dengan segera.

b. Baik bentuk maupun isi data sekunder, telah di bentuk dan disini oleh peneliti-peneliti terdahulu, sehigga peneliti kemudian, tidak mempunyai pengawasan terhadap pengumpulan, pengolahan, analisa, maupun konstruksi data.

c. Tidak terbatas oleh waktu maupun tempat.

Data sekunder, biasanya dibedakan menjadi tiga kategori, yaitu bahan hukum primer, bahan hukum sekunder dan bahan hukum tersier.

1) Bahan hukum primer, yaitu berupa ketentuan perundang-undangan yang mengikat dan peraturan lainnya.

2) Bahan hukum sekunder, yaitu bahanbahan yang menjelaskan bahan hukum primer, seperti hasil-hasil penelitian, teori, konsep pemikiran para ahli atau buku-buku yang berkorelasi dengan masalah yang di teliti. Dalam penyusunan penelitian ini, bahan hukum sekundernya, adalah buku-buku yang berkaitan langsung dengan masalah yang dikaji ,pendapat para ahli, teoriteori yang terkait dengan masalah yang diteliti, serta putusan-putusan pengadilan tentang kasus yang telah terjadi dalam masyarakat.

3) Bahan hukum tersier, yaitu bahan yang menjelaskan bahan hukum primer dan sekunder sepertinya kamus hukum.

\footnotetext{
${ }^{15}$ Op.Cit, hlm.12.
}

\section{Tinjauan Pustaka}

\section{Hak Kekayaan Intelektual Pada Umumnya}

Dalam pembahasan mengenai persoalan merek sebagai bagian dari Hak Kekayaan Intelektual, maka perlu dibahas terlebih dahulu pengertian Hak Kekayaan Intelektual. Hak Kekayaan Intelektual adalah hak kebendaan, hak atas suatu benda yang bersumber dari hasil kerja otak, hasil kerja rasio manusia ${ }^{16}$. Jadi Hak Kekayaan Intelektual pada dasarnya merupakan hak yang lahir berdasarkan hasil karya intelektual seseorang. Hak Kekayaan Intelektual merupakan konstruksi hukum terhadap perlindungan hukum Hak Kekayaan Intelektual sebagai hasil cipta karsa pencipta atau penemunya ${ }^{17}$.

Hak Kekayaan Intelektual perlu mendapatkan perlindungan hukum karena penciptaannya memerlukan waktu dan tenaga serta biaya yang besar. Pemilik Hak Kekayaan Intelektual yang telah mencurahkan karya pikiran, tenaga dan biaya adalah wajar untuk mendapatkan kompensasi apabila Hak Kekayaan Intelektual tersebut digunakan dalam bidang komersial $^{18}$. Menurut teori alam, pencipta memiliki hak moral untuk menikmati hasil ciptaannya termasuk didalamnya

\footnotetext{
${ }^{16}$ Cita Citrawinda, Op.cit, hal 17

17 Endang Purwaningsih, Hak Kekayaan Intelektual (HKI) dan Lisensi, Mandar Maju, Bandung, 2012, hal. 1

${ }^{18}$ Budi Santoso, Pengantar HKI dan Audit HKI untuk perusahaan, Pustaka Magister, Semarang, 2009, hal. 3
} 
keuntungan yang dihasilkan oleh intelektualnya $^{19}$.

Apabila tidak ada perlindungan hukum terhadap Hak Kekayaan Intelektual, bisa dipastikan akan terjadi penggunaan, peniruan, kreatifitas dan kerja keras pihak lain tanpa batas yang menyebabkan tidak adanya keuntungan ekonomis bagi penemu atau pemilik Hak Kekayaan Intelektual, yang pada akhirnya akan mematikan kreatifitas dan menghambat kemajuan peradaban manusia.

\section{Hak Merek Dan Lahirnya Undang- Undang Merek}

Agus Sardjono menyatakan bahwa Hak Kekayaan Intelektual adalah kunci untuk memenangkan persaingan di antara bangsabangsa di dunia ${ }^{20}$. Menurutnya, bangsa yang mampu memanfaatkan sistem Hak Kekayaan Intelektual dengan baik dan benar pasti mampu pula bersaing dengan bangsabangsa lain.

Merek merupakan definisi hukum yang memberikan upaya pemulihan jka suatu tanda perdagangan digunakan oleh pihak yang tidak memiliki kewenangan untuk itu. Merek bisa lebih luas atau lebih sempit dari pada nilai suatu cap. Merek pada dasarnya adalah tanda untuk mengidentifikasikan dan membedakan

\footnotetext{
${ }^{19}$ HD. Effendy Hasibuan, Perlindungan Merek, Studi mengenai Putusan Pengadilan Indonesia dan Amerika Serikat, Program Pascasarjana Fakultas Hukum Universitas Indonesia, Jakarta, 2003, hal. 16.

${ }^{20}$ Lihat Agus Sardjono, Bersaing Secara Sehat adalah Roh dari Sistem HKI, artikel terdapat di laman website; http://teknopreneur.com/content/agussardjono-bersaing-secara-sehat-adalah-roh-darisistem-hki.26 November 2010
}

produk suatu perusahaan dengan perusahaan lain.

Bagi dunia usaha, merek memiliki arti yang sangat penting dan mahal. Merek bukanlah sekedar nama tetapi mencerminkan harga diri perusahaan, pengalaman perusahaan, jaminan mutu atas produk barang dan/atau jasa yang dihasilkan perusahaan. Merek juga mencerminkan tingkat kepercayaan konsumen terhadap suatu barang dan/atau jasa. Produk dengan merek terkenal lebih mudah dipasarkan sehingga mendatangkan banyak keuntungan finansial bagi perusahaan. Berdasarkan alasan inilah maka perlindungan hukum terhadap hak merek dibutuhkan karena tiga hal yaitu ${ }^{21}$ :

a. Untuk menjamin adanya kepastian hukum bagi para penemu merek, pemilik merek, atau pemegang hak merek;

b. Untuk mencegah terjadinya pelanggaran dan kejahatan atas hak merek sehingga keadilan hukum dapat diberikan kepada pihak yang berhak;

c. Untuk memberi manfaat kepada masyarakat agar masyarakat lebih terdorong untuk membuat dan mengurus pendaftaran merek usaha mereka.

\section{Pendaftaran Merek}

Menurut Sudargo Gautama, pendaftaran merek bukan merupakan suatu kewajiban $^{22}$. Pemilik merek tidak diwajibkan dan tidak dipaksa untuk

\footnotetext{
${ }^{21}$ Iswi Hariyani, Prosedur Mengurus HAKI (Hak Atas Kekayaan Intelektual) Yang Benar, Membahas Secara Runtut Dan Detail Tentang Tata Cara Mengurus Hak Atas Kekayaan Intelektual, Pustaka Yustisia, Yogyakarta, 2010, hal. 89

22 Sudargo Gautama, Hukum Merek Indonesia, Alumni, Bandung, 1997, hal. 106
} 
mendaftarkan merek. Tiap orang yang mempunyai suatu merek dapat memakai mereknya itu tanpa mendaftarkan merekmereknya. Hal ini seringkali kurang dimengerti oleh khalayak ramai. Pada umumnya publik menganggap bahwa hanya suatu merek yang terdaftar adalah yang terkuat karena pendaftaran dianggap menciptakan hak atas suatu merek. Tetapi bukan demikian halnya, justru melalui pemakaian pertama di Indonesia adalah yang menciptakan atas suatu merek. Bukan pendaftarannya yang tidak merupakan suatu keharusan. Pendaftaran hanya memudahkan pembuktian tentang pemakaian pertama ini $^{23}$.

Secara umum, dikenal 4 (empat) sistem pendaftaran merek yang lazim digunakan di dunia, yaitu ${ }^{24}$ :

a. Pendaftaran tanpa pemeriksaan merek terlebih dahulu.

Menurut sistem ini merek yang dimohonkan pendaftaran segera didaftarkan asal syarat-syarat permohonannya telah dipenuhi, antara lain pembayaran biaya permohonan, pemeriksaan dan pendaftaran.

b. Pendaftaran dengan pemeriksaan merek terlebih dahulu

Negara-negara seperti Amerika serikat, Inggris, Jerman, dan Jepang menyelenggarakan pemeriksaan merek terlebih dahulu sebelum mendaftarkan suatu merek dalam daftar umum merek, terlebih dahulu diumumkan dalam trade

${ }^{23}$ Ibid

24 Muhamad Djumhana dan R. Djubaedillah, Hak Milik Intelektual : Sejarah, Teori Dan Prakteknya di Indonesia, Citra Aditya Bakti, Bandung, 2003, hal. 184 journal untuk jangka waktu tertentu memberikan kesempatan bagi pihakpihak yang mengajukan keberatan. Apabila dalam jangka waktu yang diberikan tidak ada keberatan-keberatan yang diajukan, maka pendaftaran merek dikabulkan.

c. Pendaftaran dengan pengumuman sementara

Sebelum merek bersangkutan didaftarkan, merek itu diumumkan terlebih dahulu untuk memberi kesempatan kepada pihak lain dengan mengajukan keberatan-keberatan tentang pendaftaran merek tersebut.

d. Pendaftaran dengan pemberitahuan terlebih dahulu tentang adanya merek lain terdaftar yang ada persamaannya.

Pemohon pendaftaran merek diberitahu bahwa mereknya mempunyai persamaan pada keseluruhan atau pada pokoknya dengan merek yang telah didaftarkan terlebih dahulu untuk barang sejenis atau nama orang lain. Walaupun demikian, jika pemohon tetap menghendaki pendaftaran mereknya, maka mereknya itu didaftarkan juga.

Prosedur permohonan pendaftaran merek di Indonesia telah diatur dalam Peraturan Pemerintah Nomor 23 Tahun 1993 Tentang Tata Cara Permohonan Pendaftaran Merek. Dalam peraturan ini sudah diatur bagaimana prosedur yang harus ditempuh seseorang untuk mendaftarkan mereknya, permohonan perpanjangan jangka waktu perlindungan hukum merek terdaftar, penghapusan pendaftaran merek oleh pemilik merek, perubahan dan penarikan kembali permohonan pendaftaran merek dan pencantuman nomor pendaftaran merek. 
Ada 2 (dua) macam stelsel pendaftaran yang dikenal dalam kepustakaan yaitu sistem konstitutif dan sistem deklaratif ${ }^{25}$ :

a. Sistem Konstitutif mengatur hak atas merek diperoleh melalui pendaftaran, artinya hak eksklusif atas suatu merek diberikan karena adanya pendaftaran. Pada sistem konstitutif, pendaftaran merek merupakan hal yang mutlak dilakukan. Merek yang tidak didaftar, otomatis tidak akan mendapatkan perlindungan hukum. Pihak berhak memperoleh hak atas suatu merek adalah pihak yang telah mendaftarkan mereknya. Pendaftaran ini menciptakan suatu hak atas merek. Pihak yang mendaftarkan, dialah satu-satunya yang berhak atas suatu merek dan pihak ketiga harus menghormati hak pendaftar sebagai hak mutlak.

b. Sistem Deklaratif mengatur pendaftaran merek tidak merupakan suatu keharusan, jadi tidak ada kewajiban untuk mendaftarkan merek. Pendaftaran hanya untuk pembuktian, bahwa pendaftaran merek adalah pemakai pertama dari merek yang bersangkutan. Pendaftaran ini tidak menerbitkan hak melainkan hanya memberikan dugaan atau sangkaan hukum (rechtsvermoeden) atau presemption iuiris yaitu bahwa pihak yang mereknya terdaftar itu adalah pihak yang berhak atas merek tersebut dan sebagai pemakai pertama dari merek yang didaftarkan.

25 Rachmadi Usman, Hukum Hak Atas Kekayaan Intelektual, : Perlindungan dan Dimensi Hukumnya di Indonesia, Alumni, Bandung, 2003, hal. 331 .
Penghapusan pendaftaran merek dari daftar umum merek dapat dilakukan oleh Dirjen HKI, baik atas keinginan sendiri maupun berdasarkan permohonan pemilik merek yang bersangkutan. Penghapusan pendaftaran dapat pula diajukan oleh pihak ketiga dalam bentuk gugatan kepada Pengadilan Niaga terhadap putusan Pengadilan Niaga hanya dapat diajukan kasasi ke Mahkamah Agung. Isi putusan yang telah berkekuatan hukum tetap segera disampaikan oleh Panitera Pengadilan kepada Ditjen HKI. Ditjen HKI kemudian melaksanakan penghapusan merek yang bersangkutan dari Daftar Umum Merek dan mengumumkan dalam Berita Resmi Merek. Penghapusan pendaftaran merek diberitahukan secara tertulis kepada pemilik merek atau kuasanya dengan menyebutkan alasan penghapusan dan penegasan bahwa sejak tanggal pencoretan dari Daftar Umum Merek dan Sertifikat Merek tersebut dinyatakan tidak berlaku lagi. Penghapusan pendaftaran merek secara otomatis mengakibatkan berakhirnya perlindungan hukum atas merek tersebut.

Dalam pengaturan merek selain dikenal mekanisme penghapusan pendaftaran merek, juga terdapat mekanisme juga terdapat mekanisme pembatalan merek yang terdaftar. Pendaftaran merek hanya bisa dimintakan pembatalannya oleh pihak yang berkepentingan yaitu antara lain jaksa, yayasan, lembaga bidang konsumen dan lembaga majelis keagamaan.

Pembatalan pendaftaran merek dilakukan oleh Ditjen HKI dengan mencoret merek yang bersangkutan dari Daftar Umum Merek dengan memberi catatan tentang alasan dan tanggal pembatalan tersebut. 
Pembatalan pendaftaran diberitahukan secara tertulis kepada pemilik merek atau kuasanya dengan menyebutkan alasan pembatalan dan penegasan bahwa sejak tanggal pencoretan dari Daftar Umum Merek dan Sertifikat Merek yang bersangkutan dinyatakan tidak berlaku lagi. Pencoretan pendaftaran suatu merek dari Daftar Umum Merek diumumkan dalam Berita Resmi Merek. Pembatalan dan pencoretan pendaftaran merek mengakibatkan berakhirnya perlindungan hukum atas merek yang bersangkutan ${ }^{26}$.

\section{Sengketa Merek}

Pemakaian merek tanpa hak dapat digugat berdasarkan perbuatan melawan hukum (Pasal 1365 KUH Perdata). Sebagai pihak penggugat harus membuktikan bahwa ia karena perbuatan melawan hukum tergugat maka penggugat menderita kerugian. Gugatan demikian bersifat keperdataan yang tidak bisa digabungkan dengan permohonan pembatalan merek sebab upaya hukumnya tunduk pada hukum acara perdata (terbuka upaya hukum banding dan kasasi). Sebaiknya gugatan ganti rugi atas perbuatan melawan hukum didahului adanya putusan gugatan pembatalan yang telah mempunyai kekuatan hukum tetap.

Sanksi pidana terhadap suatu tindakan pelanggaran hak seseorang di bidang merek, selain diatur khusus dalam ketentuan peraturan perundang-undangan merek sendiri, juga diatur dalam ketentuan KUHPidana yang terdapat dalam Pasal 393 ayat 1 dan 2 . Ketentuan sanksi pidana yang mengatur khusus tindakan pelanggaran

\footnotetext{
${ }^{26}$ Iswi Hariyani, op.cit
}

merek diatur dalam Undang-undang Nomor 15 Tahun 2001 Tentang Merek yaitu BAB XIV dalam Pasal 90 sampai dengan Pasal 95. Ketentuan khusus ini sesuai dengan asas hukum "lex specialis" dapat mengesampingkan ketentuan yang termuat dalam KUHPidana terhadap aturan yang memiliki kesamaan.

Menurut Undang-undang Nomor 15 Tahun 2001 Tentang Merek, penyelesaian sengketa merek dapat dilakukan dengan mengajukan gugatan ke Pengadilan Niaga terhadap pihak lain yang secara tanpa hak menggunakan merek yang mempunyai persamaan pada pokoknya atau keseluruhannya untuk barang atau jasa yang sejenis berupa :

a. Gugatan ganti rugi; dan/atau

b. Penghentian semua perbuatan yang berkaitan dengan penggunaan merek tersebut.

Menurut Ahmadi Miru ${ }^{27}$, gugatan ganti rugi dan atau penghentian perbuatan yang berkaitan dengan penggunaan merek secara tanpa hak tersebut memang sudah sewajarnya karena tindakan tersebut sangat merugikan pemilik merek yang sah. Penggunaan merek secara tanpa hak bukan hanya kerugian ekonomi secara langsung, tetapi juga dapat merusak citra merek tersebut apabila barang atau jasa yang menggunakan merek secara tanpa hak tersebut kualitasnya lebih rendah daripada barang atau jasa yang menggunakan merek secara sah.

Perlindungan huum atas merek kolektif sebagai Hak Kekayaan Intelektual memang

27 Ahmadi Miru dan Sutarman Yodo, Hukum Perlindungan Konsumen, Rajawali Press, Jakarta, 2004, hal. 107 
wajar, mengingat terciptanya karya-karya intelektual tersebut juga atas dasar pengorbanan yang tidak sedikit baik biaya maupun tenaga dari pemiliknya sehingga terhadapnya perlu diberikan insentif dan penghargaan guna mendorong dan merangsang seseorang untuk berkarya dan berkreativitas. Hal ini didukung oleh teoriteori dari Robert M. Sherwood terkait dengan konsepsi perlindungan hukum Hak Kekayaan Intelektual. Teori-teori yang relevan disini adalah Reward Theory, Recovery Theory, dan Incentive Theory, yang selanjutnya dapat dijelaskan sebagai berikut ${ }^{28}$ :

1. Reward Theory, berupa pengakuan terhadap karya intelektual yang dihasilkan oleh seseorang sehingga kepada penemu/pencipta atas pendesaian harus diberikan penghargaan sebagai imbalan atas upaya-upaya kreatif dalam menemukan/ menciptakan karya-karya intelektual tersebut.

2. Recovery Theory, berupa pengembalian terhadap apa yang telah dikeluarkan penemu/pencipta/pendesain, yakni biaya, waktu, dan tenaga dalam proses menghasilkan suatu karya.

3. Incentive Theory, berupa insentif yang diberikan kepada penemu/pencipta/ pendesain untuk mengembangkan kreativitas dan mengupayakan terpacunya kegiatan-kegiatan penelitian yang berguna.

Sengketa merek sendiri merupakan delik aduan. Gugatan dalam sengketa merek ditujukan kepada Pengadilan Niaga di

\footnotetext{
28 Ranti Fauza Mayana, Perlindungan Desain Industri di Indonesia Dalam Era Perdagangan Bebas, Grasindo, Jakarta, 2004
}

daerah hukum tergugat bertempat tinggal.Terhadap Putusan Pengadilan Niaga tentang gugatan atas hak merek hanya dapat diajukan kasasi. Ini berarti ada satu tahapan pemeriksaan yaitu banding ke Pengadilan Tinggi yang tidak dilalui sehingga memperpendek tahap penyelesaian sengketa.

Selain penyelesaian sengketa gugatan melalui Pengadilan Niaga, para pihak dapat menyelesaikan sengketa melalui arbitrase dan alternatif penyelesaian sengketa sebagaimana diatur dalam Undang-undang Nomor 30 Tahun 1999 Tentang Penyelesaian Sengketa yang telah mengukuhkan pengakuan urgensi lembaga "alternatif penyelesaian sengketa" atau disingkat APS dalam mekanisme penyelesaian sengketa di Indonesia. Urgensi alternatif penyelesaian sengketa di Indonesia didasari pertimbangan-pertimbangan sebagai berikut :

1. Kepentingan meningkatnya arus investasi, baik domestik maupun asing harus disertai dengan tersedianya mekanisme penyelesaian sengketa yang tidak saja adil dan menjamin kepastian hukum tetapi dapat diterima oleh semua pihak yang bersengketa karena biasanya penyelesaian sengketa yang bersifat ajudikatif, yang tidak melibatkan para pihak sebagai pengambil keputusan (kesepakatan) seringkali menimbulkan ketidakpuasan pada salah satu pihak.

2. Penyelesaian sengketa yang cepat, murah, sederhana, dan konfidental yang sangat dibutuhkan dalam sengketa yang menyangkut persoalan privat (perdata) termasuk bisnis atau perdagangan.

Berdasarkan Undang-undang Nomor 30 Tahun 1999, ada lima (5) macam cara 
alternatif penyelesaian sengketa (APS), yaitu

1. Konsultasi

Secara terminologis dapat dikatakan sebagai pertukaran pikiran untuk mendapatkan kesimpulan (nasehat, saran dan sebagainya) yang sebaik-baiknya ${ }^{29}$. Bentuk dari konsultasi adalah "dispute counseling" yang berarti suatu proses yang mana pihak ketiga (the dispute counseling) melakukan penelitian sengketa dan memberikan pada para pihak atau satu pihak yang bersengketa suatu nasehat mengenai isu yang dipertimbangkan dapat mencapai hasil yang dikehendaki atau dimungkinkan dan cara yang dapat ditempuh.

2. Negosiasi

Negosiasi berasal dari bahasa Inggris yaitu negotiation yang artinya perundingan. Dalam bahasa sehari-hari negosiasi sepadan dengan istilah berunding, bermusyawarah atau bermufakat. Orang yang mengadakan perundingan disebut negosiator. Negosiasi adalah fact of life atau keseharian. Setiap orang melakukan negosiasi untuk mendapatkan apa yang diinginkan dari orang lain $^{30}$.

3. Mediasi

Mediasi berasal dari bahasa Inggris yaitu "mediation" atau penengahan, yaitu penyelesaian sengketa yang melibatkan pihak ketiga sebagai penengah atau penyelesaian sengketa secara menengahi.

4. Konsiliasi

\footnotetext{
${ }^{29}$ Kamus Besar Bahasa Indonesia, Balai Pustaka, 1990

${ }^{30}$ Suyud Margono, ADR dan Arbitrase, Ghalia Indonesia, Jakarta, 2000, hlm 49.
}

Konsiliasi berasal dari bahasa Inggris yaitu "conciliation", yang berarti pemufakatan. Dalam Kamus Besar Bahasa Indonesia, konsiliasi diartikan sebagai usaha mempertemukan keinginan pihak yang berselisih untuk mencapai persetujuan dan menyelesaikan perselisihan. Konsiliasi juga dapat diartikan sebagai upaya membawa pihakpihak yang bersengketa untuk menyelesaikan permasalahan antara kedua belah pihak secara negosiasi.

5. Penilaian ahli

Penilaian ahli merupakan bagian proses advisory yang hanya memiliki karakter khusus yaitu proses yang mana pihak ketiga dipilih berdasarkan keahlian bidang pengetahuannya atas masalah pokok yang disengketakan.

\section{Merek Kolektif}

Menurut Pasal 1 butir 2, 3 dan 4 Undang-undang Nomor 15 Tahun 2001 Tentang Merek yaitu Merek kolektif adalah merek yang digunakan pada barang atau jasa dengan karakteristik yang sama yang diperdagangkan oleh beberapa orang atau badan hukum secara bersama-sama untuk membedakan dengan barang atau jasa sejenis lainnya. Pemilik merek kolektif terdaftar hanya dapat menggunakan merek tersebut bersama-sama dengan perusahaan, perkumpulan, atau perhimpunan lain yang juga memakai merek kolektif yang bersangkutan, apabila hal tersebut dinyatakan dengan tegas persyaratannya dalam persetujuan penggunaan merek kolektif yang dijanjikan. 
Peraturan penggunaan merek kolektif harus memuat $^{31}$ :

1. Sifat, ciri-ciri umum atau mutu dari barang atau jasa yang diproduksi dan diperdagangkannya akan menggunakan merek kolektif tersebut.

2. Ketentuan bagi pemilik merek kolektif untuk melakukan pengawasan yang efektif atas penggunaan merek tersebut dengan peraturan.

3. Sanksi atas penggunaan merek kolektif yang bertentangan dengan peraturan.

Hak atas merek kolektif terdaftar hanya dapat dialihkan kepada pihak penerima yang dapat melakukan pengawasan efektif sesuai dengan ketentuan penggunaan merek kolektif tersebut. Pengalihan hak atas merek kolektif wajib dimohonkan pencatatannya kepada Direktorat Jenderal Hak Kekayaan Intelektual dikenai biaya. Pencatatan pengalihan hak atas merek kolektif dicatat dalam Daftar Umum merek dan diumumkan dalam Berita Resmi Merek. Merek kolektif yang sudah terdaftar tidak dapat dilisensikan kepada pihak lain sebagaimana merek pada umumnya.

Penghapusan pendaftaran merek kolektif dilakukan atas dasar, yaitu ${ }^{32}$ :

1. Permohonan sendiri dari pemilik merek kolektif dengan persetujuan tertulis dari semua pemakai merek kolektif;

2. Bukti yang cukup bahwa merek kolektif tersebut dipakai selama 3 tahun berturutturut sejak tanggal pendaftarannya atau pemakaian terakhir, kecuali apabila alasan yang dapat diterima oleh Ditjen HKI;

\footnotetext{
${ }^{31}$ Iswi Hariyani, op.cit. hal. 104

${ }^{32}$ Iswi Hariyani, op.cit. hal. 112
}

3. Bukti yang cukup bahwa merek kolektif digunakan untuk jenis barang atau jasa yang tidak sesuai dengan jenis barang atau jenis jasa yang dimohonkan pendaftarannya.

4. Bukti yang cukup bahwa merek kolektif tidak digunakan sesuai peraturan penggunaan merek kolektif.

Permohonan penghapusan pendaftaran merek kolektif diajukan kepada Ditjen HKI. Penghapusan pendaftaran merek kolektif diatur dalam Daftar Umum Merek dan diumumkan dalam Berita Resmi Merek. Penghapusan pendaftaran merek kolektif dapat pula diajukan oleh pihak ketiga dalam bentuk gugatan kepada Pengadilan Niaga.

\section{E. Pembahasan}

\section{Alternatif Perlindungan Hukum Atas Hak Merek Kolektif Genteng Jatiwangi Guna Mengurangi Persaingan Usaha Di Kabupaten Majalengka}

Pada masa sekarang era perdagangan global dan pasar bebas tentang merek memegang peranan yang sangat penting yang memerlukan sistem pengaturan yang lebih memadai. Era perdagangan global hanya dapat dipertahankan jika terdapat iklim persaingan usaha yang sehat. Kebutuhan adanya perlindungan hukum atas merek semakin berkembang degan pesat setelah banyaknya orang yang melakukan peniruan. Salah satu merek yang perlu dilindungi yaitu merek Genteng Jatiwangi yang berasal dari wilayah Jatiwangi. Kabupaten Majalengka meskipun sebagai sentra Industri Genteng, akan tetapi masyarakat Majalengka umumnya dan khususnya para pengusaha Genteng merek 
Jatiwangi masih banyak yang belum mendaftarkan mereknya. Pendaftaran merek yang digunakan untuk mengidentifikasi barang dan jasa yang diproduksi atau distribusi oleh perusahaan tertentu memberikan hak kepada perusahaan untuk menggunakan secara eksklusif mereknya. Pemilik merek terdaftar memiliki hak untuk mencegah pihak lain menggunakan mereknya tanpa ijin sebagai dasar perlindungan hukum atas merek Genteng Jatiwangi. Dalam memasuki pasar bebas, perlindungan hukum atas Hak Kekayaan Intelektual di Indonesia perlu perhatian yang serius dalam menghadapi arus globalisasi baik di bidang sosial, ekonomi, budaya dan bidang-bidang lainnya.

Dalam konteks penegakan hukum, khususnya penegak hukum di bidang pelanggaran merek kolektif, maka sangat perlu untuk diperhatikan kejelasan perumusan norma dari peraturan hukumnya sendiri, yang dalam hal ini perumusan norma dari Undang-undang Nomor 15 Tahun 2001 Tentang Merek. Faktor ini sangat mempengaruhi penegakan hukum. Sebagaimana dikemukakan oleh Soerjono Soekanto $^{33}$, bahwa masalah penegakan hukum sebenarnya terletak pada faktorfaktor yang mempengaruhinya, atau dengan kata lain ada beberapa faktor yang mempengaruhi penegakan hukum, yaitu :

1. Faktor hukumnya sendiri

2. Faktor penegakan hukum

3. Faktor sarana atau fasilitas yang mendukung penegakan hukum

4. Faktor masyarakat

33 Soerjono Soekanto, Faktor-faktor yang Mempengaruhi Penegakan Hukum, Rajawali Press, Jakarta, 2008, hal. 16
5. Faktor kebudayaan

Agar peraturan yang mengatur tentang merek dapat berfungsi dengan baik, maka salah satu yang perlu diperhatikan adalah perumusan normanya yang harus jelas dan lengkap dari peraturan tersebut, sehingga nantinya peraturan tersebut dapat dilaksanakan atau ditegakan secara konsekuen.

Undang-undang Nomor 15 Tahun 2001 Tentang Merek sebagai ketentuan hukum harus dilaksanakan dan ditegakan, agar pelaku pelanggaran merek dapat diberikan sanksi hukum sesuai dengan tingkat pelanggarannya. Agar Undang-undang merek tersebut dapat ditegakan, maka undang-undang tersebut harus memenuhi kepastian hukum dalam hal perumusan normanya. Dengan penegakan hukum secara terus menerus akan menumbuhkan kepatuhan hukum masyarakat atau aparat penyelenggaraan negara. Kerancuan yang dihadapi oleh aparat penegak hukum, khususnya pada negara-negara yang sedang membangun, antara lain :

1. Materi peraturan perundang-undangan tidak lengkap dan tidak jelas.

2. Materi peraturan perundang-undangan sudah tidak sesuai.

Seyogyanya perkembangan pembangunan dan masyarakat dapat diimbangi pembuat undang-undang. Dengan demikian, akan dapat dirasakan oleh setiap anggota masyarakat dan orang yang termasuk penyelenggara negara bahwa pematuhan hukum merupakan hal yang terbaik. Mengingat demikian penting arti dan peranan merek dalam dunia industri dan perdagangan, maka sudah seharusnya jika hak merek yang dimiliki perusahaan atau 
seseorang yang secara yuridis dari perbuatan-perbuatan yang mengarah pada pemakaian merek secara salah atau melawan hukum. Perlindungan hukum tersebut berfungsi untuk memproteksi suatu hak merek dari perbuatan yang mengarah pada perbuatan melawan hukum yang dilakukan orang-orang yang tidak bertanggungjawab ${ }^{34}$.

Konsep perlindungan hukum terhadap hak merek mengacu pada sifat hak merek yang bersifat khusus. Karena sepadan dengan hak kebendaan lainnya, maka hak merek secara ekonomis memiliki nilai yang tinggi. Dengan demikian, maka semakin terdorong perlunya perlindungan hukum atas merek kolektif.

Sebagai salah satu Hak Kekayaan Intelektual, merek memiliki fungsi yang sangat penting dan strategis. Pentingnya hak merek tidak hanya pada pembedaan barang dan jasa sejenis saja, melainkan juga berfungsi sebagai aset perusahaan yang tidak ternilai harganya.

\section{Peran Pemerintah Daerah Kabupaten} Majalengka Terhadap Hak Merek Kolektif Dalam Melindungi Keberadaan Genteng Jatiwangi

Pemerintah daerah memiliki peranan yang sangat penting dalam meningkatkan kesejahteraan masyarakat dan setiap urusan yang menyangkut kepentingan warga tidak boleh dibiarkan begitu saja termasuk didalamnya adalah persoalan-persoalan yang menyangkut kegiatan industri genteng Jatiwangi Kabupaten Majalengka.

\footnotetext{
${ }^{34}$ Insan Budi Maulana, Sukses Bisnis Melalui Merek, Paten, Dan Hak Cipta, Citra Aditya Bakti, Bandung, 1997, hal 25
}

Disadari atau tidak, sektor industri genteng Jatiwangi Kabupaten Majalengka telah membantu pemerintah dalam program pengentasan kemiskinan, yaitu dengan banyaknya warga yang bekerja di sektor tersebut. Namun demikian, dengan berkurangnya pengangguran bukan berarti industri genteng Jatiwangi Kabupaten Majalengka bebas dari masalah dan persoalan lain timbul akibat tidak dipatuhinya peraturan yang ada.

Pelaku usaha kecil sentra industri genteng Jatiwangi cenderung melihat Undang-Undang Nomor 15 Tahun 2001 Tentang Merek tidak terlalu berpengaruh terhadap kegiatan usaha. Padahal pendaftaran Merek terhadap genteng Jatiwangi Kabupaten Majalengka bukanlah hanya sekedar catatan, tetapi juga memiliki manfaat yang sangat besar. Dan pemerintah daerah harus dapat merubah pandangan pelaku usaha kecil sentra industri genteng Jatiwangi Kabupaten Majalengka yang demikian itu. Seseorang akan sulit mematuhi peraturan apabila ia tidak tahu apa yang akan ia peroleh jika mematuhinya.

Transformasi pengetahuan terkait erat dengan proses sosialisasi yang dilakukan. Dengan sosialisasi, masyarakat dapat mengerti dan memahami akan pentingnya sebuah aturan. Selama ini, sosialisasi Undang-Undang Nomor 15 Tahun 2001 Tentang Merek, termasuk didalamnya pendaftaran Merek yang harus dilakukan masih jauh dari maksimal. Pemerintah daerah masih jarang memberikan arahan dan pembinaan terhadap pelaku usaha kecil terhadap sentra industri genteng Jatiwangi Kabupaten Majalengka. Akibatnya banyak pelaku usaha kecil genteg Jatiwangi 
Kabupaten Majalengka yang tidak tahu terhadap peraturan yang ada.

Sesungguhnya, apabila banyak perusahaan yang terdaftar maka akan meningkatkan pendapatan asli daerah akan tetapi pada kasus sentra industri genteng Jatiwangi Kabupaten Majalengka, alih-alih menambah pendapatan, perusahaan yang mendaftar pun tidak ada. Keterbatasan modal yang menjadi kendala pelaku usaha kecil genteng Jatiwangi harus dicarikan solusinya.

Pemerintah semestinya memberikan kemudahan-kemudahan sehingga kendala biaya dapat teratasi. Sebenarnya melalui Undang-Undang Nomor 9 Tahun 1995 Tentang Usaha Kecil telah memberikan kebijaksanaan untuk memperluas sumber pendanaan, meningkatkan akses terhadap sumber pendanaan dan memberikan kemudahan dalam pendanaan, namun demikian, pada kenyataannya kebijaksanaan itu hanyalah sebatas yang tertulis dalam undang-undang saja. Undang-Undang Nomor 9 Tahun 1995 Tentang Usaha Kecil pada Pasal 21 menyatakan bahwa pemerintah, dunia usaha dan masyarakat menyediakan pembiayaan yang meliputi :

a. Kredit perbankan;

b. Pinjaman lembaga keuangan bukan bank;

c. Modal ventura;

d. Pinjaman dari dana penyisihan sebagian laba Badan Usaha Milik Negara (BUMN);

e. Hibah; dan,

f. Jenis pembiayaan lainnya.

Dalam menghadapi era perdagangan global dan memasuki pasar bebas maka perlindungan hukum atas merek kolektif sangat penting. Genteng Jatiwangi sebagai andalan Pemerintah Daerah Kabupaten Majalengka perlu banyak perhatian yang lebih serius dalam perlndungan hukumnya. Hal ini disebabkan hampir semua genteng Jatiwangi Kabupaten Majalengka belum mendapat perlindungan hukum terhadap merek kolektif karena mayoritas belum terdaftar di Direktorat Jenderal Hak Kekayaan Intelektual. Pemerintah Daerah Majalengka selama ini kurang perhatian terhadap perlindungan hukum merek genteng Jatiwangi sebagai salah satu industri andalan Majalengka. Para pemilik industri genteng Jatiwangi ini merasa kurang diperhatikan oleh Pemerintah Daerah Majalengka khususnya Dinas Perindustrian, Perdagangan dan Koperasi. Pemerintah Daerah Kabupaten Majalengka sebaiknya lebih banyak berperan agar merek genteng Jatiwangi tetap eksis keberadaannya dan mendapat perlindungan hukum sebagaimana peraturan perundang-undangan yang berlaku. Sentra industri genteng Jatiwangi mempunyai kontribusi yang banyak terhadap perekonomian masyarakat Majalengka.

Perhatian Pemerintah Daerah Kabupaten Majalengka terhadap sentra industri andalannya khususnya terutama pada industri genteng Jatiwangi masih kurang dan hal ini disebabkan karena :

1. Sosialisasi tentang Hak Kekayaan Intelektual khususnya tentang Merek, masih sangat jarang sehingga intensitas perlu ditingkatkan lebih banyak lagi karena salah satu penyebab pemilik genteng merek Jatiwangi tidak mendaftarkan mereknya disebabkan ketidaktahuan akan perlindungan hukum terhadap merek kolektif. 
2. Pemerintah Daerah mendukung adanya alternatif perlindungan hukum atas merek kolektif terhadap genteng Jatiwangi, namun Dinas Perindustrian, Perdagangan dan Koperasi tidak memiliki alokasi anggaran untuk biaya pendaftaran sampai keluarnya sertifikat merek.

\section{F. Penutup}

\section{Kesimpulan}

1. Merek kolektif dapat dijadikan alternatif perlindungan hukum merek genteng Jatiwangi di Kabupaten Majalengka. Meskipun Majalengka sebagai sentra industri genteng Jatiwangi yang mencapai ratusan, namun faktanya mayoritas genteng Jatiwangi di Kabupaten Majalengka belum mendapat perlindungan hukum karena belum terdaftar di Direktorat Jenderal Hak Kekayaan Intelektual sebagaimana diatur dalam Undang-undang Nomor 15 Tahun 2001 Tentang Merek. Maka penggunaan merek kolektif dapat dijadikan sebagai alternatif perlindungan hukum terhadap merek genteng Jatiwangi di Kabupaten Majalengka yang sebagian besar dimiliki Unit Usaha Kecil dan Menengah (UKM). Dengan menggunakan merek kolektif dan pemasaran bersama dapat mengurangi tingkat persaingan usaha tidak sehat di antara para pemilik industri genteng Jatiwangi d Kabupaten Majalengka.

2. Pemerintah Daerah Kabupaten Majalengka melalui Dinas Perindustrian, Perdagangan dan Koperasi mendukung penggunaan merek kolektif sebagai alternatif perlindungan hukum merek genteng Jatiwangi di Kabupaten Majalengka. Dukungan Pemerintah Daerah dengan sosialisasi-sosialisasi tentang pentingnya perlindungan hukum Hak Kekayaan Intelektual khususnya merek sehingga para pengusaha genteng Jatiwangi memahami dan menyadari akan pentingnya perlindungan hukum merek sehingga segera mendaftarkan merek gentengnya ke Direktorat Jenderal Hak Kekayaan Intelektual. Pemerintah Daerah Kabupaten Majalengka menyadari bahwa industri genteng merk Jatiwangi mempunyai peran yang penting bagi perekonomian masyarakat Majalengka karena banyak menyerap tenaga kerja dan mempunyai investasi yang besar dibandingkan dengan industri lainnya dalam menjaga keberadaan genteng Jatiwangi menghadapi era perdagangan global.

\section{Saran}

1. Dalam rangka meningkatkan pemahaman mengenai pentingnya perlindungan Hak kekayaan Intelektual khususnya perlindungan hukum merek lebih diperbanyak sosialisasi dan penyuluhan hukum khususnya para pemilik usaha genteng Jatiwangi oleh Pemerintah Daerah Kabupaten Majalengka atau pihak-pihak terkait seperti Dinas Perindustrian dan perdagangan agar pemilik usaha genteng Jatiwangi lebih memahami dan menyadari akan pentingnya perlindungan hukum merek sehingga bisa mendaftarkan mereknya.

2. Perlunya penegakan hukum yang tegas dan memberi sanksi pidana maupun 
Jurnal Unifikasi, ISSN 2354-5976

Vol. 3 No. 2 Juli 2016

sanksi perdata bagi para pelanggar merek agar para pelaku merasa jera dan tidak terulang kembali sehingga menyadari akan pentingnya perlindungan hukum terhadap merek khususnya dan Hak Kekayaan Intelektual pada uumnya.

3. Pemerintah Daerah Kabupaten

Majalengka sebaiknya memfasilitasi perlindungan hukum terhadap Hak Kekayaan Intelektual yang ada di daerahnya dengan cara mengalokasikan Anggaran Pendapatan Belanja Daerah untuk pengurusan Hak Kekayaan Intelektual agar dilindungi oleh hukum.

\section{DAFTAR PUSTAKA}

Abdul Manan, Aspek-aspek Pengubah Hukum, Kencana, Jakarta, 2005

Adrian Sutedi, Hak atas Kekayaan Intelektual, Sinar Grafika, Jakarta, 2013

Agus Sardjono, Makalah bahan seminar dengan tema " Sejarah Dan Perkembangan HAKI Indonesia”, Jakarta, 20 September 2009

Ahmadi Miru dan Sutarman Yodo, Hukum Perlindungan Konsumen, Rajawali Press, Jakarta, 2004

Budi Agus Riswandi, Hak Kekayaan Intelektual Dan Budaya Hukum, Rajawali Press, Jakarta, 2005

Budi Santoso, Pengantar HKI dan Audit HKI untuk perusahaan, Pustaka Magister, Semarang, 2009

Cita Citrawinda Priapantja, Hak atas Kekayaan Intelektual : Tantangan Masa Depan, Badan Penerbit Fakultas Hukum Universitas Indonesia, 2003

Direktorat Jenderal Hak Kekayaan Intelektual Departemen Kehakiman dan HAM RI , Buku Panduan Hak Kekayaan Intelektual, Dirjen HAKI Departemen Kehakiman dan HAM RI, Tangerang, 2003

Endang Purwaningsih, Hak Kekayaan Intelektual (HKI) dan Lisensi, Mandar Maju, Bandung, 2012

Endang Sutrisno, Bunga Rampai Hukum Dan Globalisasi, Genta Press, Yogyakarta, 2007

HD. Effendy Hasibuan, Perlindungan Merek, Studi mengenai Putusan Pengadilan Indonesia dan Amerika Serikat, Program Pascasarjana Fakultas Hukum Universitas Indonesia, Jakarta, 2003

Insan Budi Maulana, Sukses Bisnis Melalui Merek, Paten, Dan Hak Cipta, Citra Aditya Bakti, Bandung, 1997

Iswi Hariyani, Prosedur Mengurus HAKI (Hak Atas Kekayaan Intelektual) Yang Benar, Membahas Secara Runtut Dan Detail Tentang Tata Cara Mengurus Hak Atas Kekayaan Intelektual, Pustaka Yustisia, Yogyakarta, 2010

Kamus Besar Bahasa Indonesia, Balai Pustaka, Jakarta, 1990

Muhamad Djumhana dan R. Djubaedillah, Hak Milik Intelektual : Sejarah, Teori Dan Prakteknya di Indonesia, Citra Aditya Bakti, Bandung, 2003

Ok Saidin, Aspek Hukum Kekayaan Intelektual, PT. Raja Grafindo Persada, Jakarta, 2004

R. Subekti dan R. Tjitrosudibyo, Kitab Undang-Undang Hukum Perdata, Pradya Paramita, Jakarta, 1986. 
Jurnal Unifikasi, ISSN 2354-5976

Vol. 3 No. 2 Juli 2016

Rachmadi Usman, Hukum Hak Atas Kekayaan Intelektual, : Perlindungan dan Dimensi Hukumnya di Indonesia, Alumni, Bandung, 2003

Ranti Fauza Mayana, Perlindungan Desain Industri di Indonesia Dalam Era Perdagangan Bebas, Grasindo, Jakarta, 2004

Satjipto Rahardjo, Pendidikan Hukum Sebagai Pendidikan Manusia, Genta Publishing, Yogyakarta, 2009

Sudargo Gautama, Hukum Merek Indonesia, Alumni, Bandung, 1997

Suyud Margono, Komentar Atas Undang-Undang Rahasia Dagang, Desain Industri, Desain Letak Sirkuit Terpadu, CV. Novindo Pustaka Mandiri, Jakarta, 2001

Suyud Margono, ADR dan Arbitrase, Ghalia Indonesia, Jakarta, 2000

Soerjono Soekanto, Pengantar Penelitian Hukum.cet.2007, ( Jakarta : UI Press, 1984) Jakarta, 2008 Faktor-faktor yang Mempengaruhi Penegakan Hukum, Rajawali Press,

Lihat Agus Sardjono, Bersaing Secara Sehat adalah Roh dari Sistem HKI, artikel terdapat di laman website; http://teknopreneur.com/content/agus-sardjono-bersaing-secara-sehatadalah-roh-dari-sistem-hki.26 November 2010 